\title{
PENGEMBANGAN MEDIA BLOG SEBAGAI SARANA INFORMASI UNTUK MENINGKATKAN KEMAMPUAN PERENCANAAN KARIR DI SMAN 1 BULUKUMBA
}

\author{
Andi Fatmayanti \\ Dosen Jurusan Ekonomi, STKIP-PI Makassar \\ Email: cadandagirl@ymail.com
}

\begin{abstract}
This research is a Media Development Blog as a Means of information to enhance the planning careers in SMAN 1 Bulukumba that berujuan: (1) to describe the career guidance needs of students at SMA Negeri 1 Bulukumba); (2) to determine the profile of media use blogs as a means of information in improving the ability of career planning at SMA Negeri 1 Bulukumba); (3) to determine the effectiveness of blogs as a means of information media in enhancing the ability of career planning at SMA Negeri 1 Bulukumba. This study uses research and development developed by Dick \& Carey. Analysis of data using statistical analyzes non-parametric Wilcoxon signed ranks test. The results showed (1) Career Guidance blog has utility value, feasibility and accuracy; (2) blog career guidance both as a means of career information for students at SMA Negeri 1 Bulukumba; (3) blog Career guidance is effective as a means of information in improving the ability of career planning at SMA Negeri 1 Bulukumba.
\end{abstract}

Keywords : Media Blog, Career Information, Career Planning.

\begin{abstract}
Abstrak. Penelitian ini adalah penelitian Pengembangan Media Blog sebagai Sarana Informasi untuk meningkatkan kemampuan perencanaan karir di SMAN 1 Bulukumba yang berujuan: (1) untuk mengetahui gambaran kebutuhan siswa akan bimbingan karir di SMA Negeri 1 Bulukumba); (2) untuk mengetahui profil penggunaan media blog sebagai sarana informasi dalam meningkatkan kemampuan perencanaan karir di SMA Negeri 1 Bulukumba); (3) untuk mengetahui efektifitas media blog sebagai sarana informasi dalam meningkatkan kemampuan perencanaan karir di SMA Negeri 1 Bulukumba. Penelitian ini menggunakan metode penelitian dan pengembangan yang dikembangkan oleh Dick \& Carey. Analisis data menggunakan analisis statistic non parametric wilcoxon signed ranks test. Hasil penelitian ini menunjukkan (1) blog Bimbingan Karir memiliki nilai kegunaan, kelayakan dan ketepatan; (2) blog bimbingan karir baik dpergunakan sebagai sarana informasi karir bagi siswa di SMA Negeri 1 Bulukumba; (3) blog Bimbingan karir efektif digunakan sebagai sarana informasi dalam meningkatkan kemampuan perencanaan karir di SMA Negeri 1 Bulukumba.
\end{abstract}

Kata Kunci : Media blog, Informasi Karir, Perencanaan Karir.

\section{PENDAHULUAN}

Masa sekolah menengah atas adalah masa dimana para remaja diperhadapkan oleh pilihanpilihan hidup, tidak terkecuali pilihan mengenai karir, namun banyak orang yang kemudian tidak sukses dalam karirnya dikarenakan kurangnya pemahaman mengenai pilihan karirnya sendiri.
Kegagalan dalam karir tentunya berdampak negatif tidak hanya dalam hal materi namun tentunya aspek psikologis, ini dikarenakan karier tidak hanya menentukan apa yang akan dilakukan seseorang untuk mencari nafkah namun mempengaruhi hidup seseorang secara keseluruhan, termasuk kesehatan fisik dan mental. 
Di lingkungan pendidikan formal dalam hal ini sekolah menengah atas, telah dilakukan cara untuk mengatasi kegagalan seseorang dalam karirnya, yaitu melalui program bimbingan dan konseling. Namun perjalanan program bimbingan dan konseling di sekolah tidaklah semulus yang diinginkan. Banyak tantangan yang dihadapi oleh guru pembimbing di sekolah mulai dari segi pendanaan, ruangan yang kurang memadai, fasilitas yang tidak lengkap, waktu untuk melaksanakan program bimbingan dan konseling, yang di sisi lain, pimpinan sekolah dan para pendidik yang lain sering menanyakan sejauh mana kinerja guru pembimbing di sekolah, yang kemudian menimbulkan pesimistis dari segi kerbermaknaan guru pembimbing di sekolah.

Berdasarkan analisis kebutuhan yang peneliti lakukan di SMA Negeri 1 Bulukumba, disimpulkan bahwa guru pembimbing di sekolah tersebut tidak memiliki jam khusus dalam pelaksanaan program BK tidak terkecuali bimbingan karir. Informasi karir diperoleh siswa hanya dari brosur yang dibagikan oleh mahasiswa yang berkunjung ke sekolah tersebut dalam rangka pengenalan kampus mereka, brosur tersebut kemudian ada yang ditempel di mading sekolah. Kegiatan itupun hanya berlangsung pada akhir tahun ketika siswa kelas tiga telah mendekati waktu kelulusan.

Dampak negatif dari tidak terlaksananya bimbingan karir di sekolah yaitu terdapat siswa kelas tiga yang masih bingung akan pilihan karirnya termasuk pemilihan studi lanjut. Sementara itu di SMA Negeri 1 Bulukumba tersedia wifi yang dapat diakses baik oleh guru maupun siswa. Terkait dengan permasalahan tersebut, tentunya guru pembimbing perlu mencari cara agar para siswa memperoleh bimbingan karir sesuai dengan yang semestinya.

Blog dalam dunia pendidikan telah dimanfaatkan untuk memperoleh informasi. Ini dikenal dengan sebutan blog pendidikan yaitu blog yang ditulis oleh pelajar, guru, atau para pekerja di bidang pendidikan. Tidak terkecuali dalam bimbingan dan konseling. Hal ini dibuktikan oleh penelitian yang dilakukan oleh Handono (2013) yang menyimpulkan bahwa pengembangan materi layanan informasi studi lanjut melalui media blog di SMA Negeri 4 Bojonegoro layak diberikan kepada siswa.

Ini membuktikan bahwa pelaksanaan bimbingan karir tidak hanya dapat dilakukan dengan ceramah, diskusi, karyawisata, buku panduan dan konferensi karir, namun guru pembimbing dapat memanfaatkan media sosial yaitu blog untuk pemenuhan informasi karir bagi siswa.

Blog memenuhi kriteria suatu media yang digunakan dalam pendidikan. Hal ini karena blog sangat fleksibel dalam penggunaannya karena dapat diakses kapanpun dan dimanapun. Berdasarkan pemaparan di atas maka peneliti tertarik untuk mengembangkan blog sebagai media yang kelak dapat digunakan dalam pelaksanaan bimbingan karir di sekolah yang kemudian diberi nama Blog Bimbingan Karir.

Kajian pustaka yang berkaitan dengan Media Pendidikan menurut Rossi (Sanjaya, 2008): Alatalat semacam radio dan televisi kalau digunakan dan diprogram untuk pendidikan, maka merupakan media pembelajaran. Namun demikian, media bukan hanya berupa alat atau bahan saja, akan tetapi hal-hal lain yang memungkinkan siswa dapat memperoleh pengetahuan sebagaimana dikemukakan Majid (2005: 24) pengembangan pembelajaran adalah suatu proses mendesain pembelajaran secara logis dan sistematis dalam rangka untuk menetapkan segala sesuatu yang akan dilaksanakan dalam proses kegiatan belajar dengan memperhatikan potensi dan kompetensi siswa

Terdapat jenis- jenis media pendidikan diantaranya menurut Munir (2008:138), yaitu: Media pembelajaran sederhana dan media pembelajaran modern. Media pembelajaran sederhana meliputi papan tulis, sedangkan media pembelajaran modern meliputi komputer dan internet.

Blog sebagai salah satu aplikasi internet merupakan singkatan sejenis website pribadi yang dapat digunakan untuk menuliskan suatu pesan atau informasi secara terus menerus dan mempublikasikannya. (Heni Setyani: 2013). Terdapat berbagai jenis blog diantaranya adalah blog pendidikan, yaitu blog yang dibuat oleh seseorang yang berkecimpung di dalam dunia pendidikan termasuk dalam hal ini guru BK atau mahasiswa. Contohnya adalah blog yang dikembangkan oleh peneliti yaitu Blog Bimbingan Karir. Ini terkait dengan tujuan dari pengembangan media blog ini yaitu agar pelaksanaan bimbingan karir di sekolah dapat berjalan dengan efektif, sehingga para peserta 
didik dapat memperoleh pelayanan dalam hal bimbingan karir sesuai dengan yang semestinya.

Tujuan umum media blog dalam layanan informasi menurut Handono (2013: 112) adalah:

1. sebagai media penunjang pelaksanaan bimbingan dan konseling di sekolah

2. sebagai alat bantu dalam kegiatan layanan informasi

3. sebagai media yang dapat mengefisiensi waktu peserta didik dan konselor

4. sarana yang mempermudah konselor dalam penyampaian materi informasi, khususnya perguruan tinggi

5. sarana informasi dan komunikasi antara konselor dengan peserta didik tanpa tatap muka.

Sedangkan tujuan khusus media menurut Handono (2013:112) adalah:

1. Dapat mempermudah peserta didik dalam mengakses informasi materi studi lanjut

2. Dapat mengefisiensi waktu konselor dan peserta didikdalam kegiatan layanan informasi BK di sekolah

3. Internet merupakan media yang cukup digemari oleh remaja sekarang

4. Perkembangan teknologi informasi dapat dimanfaatkan oleh konselor dan peserta didik ke arah yang positif.

5. Mempermudah konselor dan peserta didik dalam kegiatan layanan informasi

6. Sebagai media pendukung dalam kegiatan layanan informasi di sekolah

Kajian yang berkaitan dengan Informasi Karir menurut Nursalim (Efendi, 2014), layanan informasi ialah kegiatan bimbingan untuk membantu siswa dalam mengenal lingkungannya yang dapat dimanfaatkan untuk saat sekarang maupun yang akan datang. Pemahaman yang diperoleh melalui layanan informasi digunakan sebagai acuan dalam meningkatkan kegiatan dan prestasi belajar, mengembangkan cita-cita, menyelenggarakan kehidupan sehari-hari dalam mengambil keputusan.

Terkait dengan pemanfaatan media dalam pelaksanaan bimbingan karir sebagai sarana informasi karir bagi siswa maka pengadaan media dapat menggunakan media yang sudah ada yang dibuat oleh pihak tertentu (produsen media) dan kita dapat langsung menggunakannya. menurut Santosa (2007) untuk membuat blog terdapat bebarapa hal yang perlu dilakukan, yaitu: email, memilih tipe blog dan memilih penyedia blog yang ada secara onlineseperti blogger, multiply, blogsome, wordpress dan lainnya.

Kajian yang berkaitan dengan perencanaan karir dikemukakan oleh Sukardi (Falentini, 2013:311) bahwa perencanaan karir merupakan proses seseorang individu untuk memilih dan memutuskan karir yang hendak dijalaninya yang berlangsung seumur hidup.

Berikut ini adalah teori perencanaan karir yang dikemukakan oleh Splete \& Pietrofesa dalam Purnamasari (2006:41), teori ini mengemukakan beberapa hal yang mesti diperhatikan oleh seseorang ketika hendak berkarir pada bidang tertentu, yaitu:

1. Memahami proses pengambilan keputusan karir, dengan mempertimbangkan:
a. Faktor-faktor psikologis dan sosiologis
b. Kesiapan dalam membuat keputusan karir
c. Aspirsi
d. Persepsi

2. Pemahaman diri

3. Pengetahuan tentang karir, yang menyangkut hal-hal sebagai berikut:

a. Tugas-tugas yang harus dilakukan dalam suatu jenis pekerjaan

b. Persyaratan kerja

c. Pendidikan

d. Training atau pelatihan khusus

4. Mempertimbangkan alternatif pilihan karir dan dampaknya baik secara fisik, intelektual dan emosional.

5. Memilih, merencanakan dan bertindak untuk mencapai pilihan karir yang diinginkan.

Terkait dengan perbedaan antara seseorang yang telah memiliki perencanaan karir dan yang tidak, berikut ini dipaparkan mengenai ciri-ciri seseorang yang telah memiliki perencanaan karir yaitu pendapat dari Yusuf (Nurjannah, 2013:15) beliau mengemukakan empat ciri-ciri seseorang yang memiliki perencanaan karir, yaitu (1) mengetahui cara memilih program studi, (2) mempunyai motivasi untuk mencari informasi tentang karir, (3) dapat memilih pekerjaan yang baik sesuai dengan bakat, minat, dan kemampuan, dan (4) mampu memilih perguruan tinggi setelah lulus sekolah.

\section{METODE}

Penelitian ini menggunakan metode Penelitian dan Pengembangan atau Research and Development dimana peneliti akan 
mengembangkan sebuah media yaitu media blog yang nantinya akan dimanfaatkan sebagai sarana informasi karir bagi siswa.

Prosedur pengembangan dalam penelitian ini mengacu pada model yang dirancang dan dikembangkan oleh Dick \& Carey yang telah disesuaikan dengan kebutuhan penelitian yaitu:

1. Studi awal

a. Analisis kebutuhan dan tujuan

b. Analisis pelaksanaan bimbingan dan konseling

c. Mengembangkan instrument

d. Mengembangkan dan memilih bahan bimbingan

2. Uji coba prototype bahan secara perorangan

Uji coba perorangan ini dilakukan untuk memperoleh masukan awal tentang kegunaan, kelayakan), dan ketepatan produk atau rancangan tertentu. Uji coba perorangan dilakukan kepada subjek 1-3 orang yaitu ahli bimbingan, ahli media, dan praktisi BK. Setelah dilakukan uji coba perorangan, produk atau rancangan direvisi. 3. Uji coba kelompok kecil

Uji coba ini bertujuan untuk mengukur keberterimaan blog sebagai sarana informasi bagi siswa yang diukur dengan menggunakan angket, dengan rumus:

$$
\bar{X}=\frac{\sum X}{N}
$$

Uji coba ini melibatkan subjek yang terdiri atas 6-8 subjek. Hasil uji coba kelompok kecil ini dipakai untuk melakukan revisi produk atau rancangan.

4. Uji coba lapangan.

Uji coba ini bertujuan untuk menguji efektifitas blog dalam meningkatkan perencanaan karir yang penghitungannya menggunakan analisis non parametrik yaitu wilcoxon melalui analisisnya SPSS 20 dan melibatkan subjek dalam kelas yang lebih besar hingga 15-30 subjek

Subjek dalam penelitian ini terdiri dari ahli bimbingan, ahli media, praktisi BK dan siswa. Adapun siswa yang menjadi subjek uji coba dalam penelitian ini adalah siswa kelas $\mathrm{X}$ di SMA Negeri 1 Bulukumba yang diambil dengan menggunakan teknik sampling bertujuan

Jenis data yang dikumpulkan berupa data kuantitatif dan kualitatif, meliputi skala penilaian dan catatan dari para penguji. Data kuantitatif diperoleh dari hasil angket penilaian. Sedangkan kualitatif didapatkan berdasarkan hasil saran dan komentar penilaian ahli dan uji lapangan.

Instrumen yang digunakan dalam penelitian ini terdiri wawancara, lembar evaluasi siswa dan angket. Sementara teknik analisis data yang digunakan dalam penelitian ini terdiri dari analisis statistik dan nonstatistik

Angket yang digunakan dalam penelitian ini adalah angket dengan bentuk checklist dengan lima pilihan jawaban. Adapun pemberian skor untuk setiap kategori yaitu sebagai berikut:

\begin{tabular}{cc}
\hline Kategori & Skor \\
\hline Sangat Sesuai & 5 \\
\hline Sesuai & 4 \\
\hline Cukup Sesuai & 3 \\
\hline Tidak Sesuai & 2 \\
\hline Sangat Tidak Sesuai & 1 \\
\hline
\end{tabular}

\section{HASIL DAN PEMBAHASAN}

1. Studi awal

a. Analisis kebutuhan dan tujuan

Dari hasil wawancara dengan guru BK di SMA Negeri 1 Bulukumba diperoleh informasi bahwa Pelaksanaan bimbingan karir sendiri belum pernah dilaksanakan oleh guru BK dikarenakan tidak adanya jam khusus bagi guru BK untuk melaksanakan tugasnya di sekolah tersebut di sisi lain banyak siswa yang ketika telah berada di kelas tiga merasa bingung akan pilihan studi lanjutnya. Olehnya itu peneliti menawarkan cara baru

pelaksanaan bimbingan karir di sekolah yaitu dengan menggunakan blog yang diberi nama blog Bimbingan Karir.

b. Analisis pelaksanaan bimbingan dan konseling

1) Karakteristik peserta didik

2) Secara umum siswa di SMA Negeri 1 Bulukumba belum memiliki perencanaan karir yang baik.

3) SMA Negeri 1 Bulukumba memiliki wifi yang dapat dimanfaatkan oleh para guru dan peserta didik. Selain itu guru 
pembimbing cukup memiliki kemampuan dalam menggunakan komputer, bahkan beberapa guru pembimbing telah memanfaatkan internet khususnya media sosial dalam kesehariannya yaitu facebook dan BBM.

c. Mengembangkan instrument

1) Angket.

Angket yang pertama untuk mengukur keberterimaan blog bagi siswa sebagai sarana informasi karir 30 item. Angket yang kedua bertujuan menguji efektifitas blog dalam meningkatkan perencanaan karir. berjumlah 41 item. Sebelum diberikan ke siswa, terlebih dahulu divalidasi oleh validator yaitu bapak Dr. Abdullah Sinring, M. Pd dan bapak Dr. Abd.Haling, M.Pd

2) Lembar evaluasi siswa

Lembar evaluasi siswa bertujuan untuk memperoleh informasi mengenai pendapat siswa terhadap kegiatan bimbingan karir yang telah dilakukan.

3) Wawancara

wawancara dipergunakan baik kepada guru pembimbing maupun kepada siswa. Wawancara pada guru dilakukan pada tahap analisis kebutuhan sementara wawancara pada siswa dilakukan dalam proses pengambilan sampel.

d. Mengembangkan dan memilih bahan bimbingan

Adapun dalam pelaksanaannya dibutuhkan media lain dalam mendukung pencapaian tujuan, yaitu:

1) Leptop/ komputer

2) Modem/ wifi

2. Uji coba prototype bahan secara perorangan. Berdasarkan penilaian yang dilakukan ahli bimbingan, ahli media, dan praktisi BK. diperoleh kesimpulan bahwa Blog Bimbingan Karir memiliki nilai kegunaan, kelayakan dan ketepatan (accuracy).

3. Uji coba kelompok kecil (small group tryout). Jumlah sampel yang digunakan pada tahap ini sebanyak 6 orang siswa kelas $\mathrm{X}$ yang diketahui belum memiliki perencanaan karir yang baik

Berdasarkan hasil dari lembar evaluasi siswa diperoleh berbagai pendapat dari siswa mengenai kegiatan bimbingan karir berbasis blog, diantaranya mereka merasa senang mengikuti kegiatan ini, memiliki pengetahuan baru mengenai jenis-jenis studi lanjut serta pemahaman mengenai perencanaan karir. Melalui lembar evaluasi ini dieroleh juga saran perbaikan dalam hal ukuran huruf yang dipergunkan dalam blog, dimana ukuran huruf dalam blog tersebut perlu ditambah, adapun hasil perbaikan dari uji kelompok kecil ini menjadi revisi kedua yang dimana revisi pertama diperoleh dari perbaikan hasil uji coba prototype. Selanjutnya berdasarkan hasil analisis angket dengan rumus

$$
\begin{aligned}
& \bar{X}=\frac{\sum X}{N} \quad \text { Setyosari, 2013: 243) } \\
& \bar{X}=\frac{702}{6}=117 \\
& \text { Dimana: } \\
& \bar{X} \quad: \text { rata-rata } \\
& \sum^{X} X: \text { jumlah skor keseluruhan } \\
& \mathrm{N} \quad \text { : jumlah individu. }
\end{aligned}
$$

Berdasarkan rumus diatas diperoleh skor ratarata yaitu 117, berdasarkan pengkategorian, nilai 117 berada pada kategori baik. Oleh karena itu disimpulkan bahwa blog bimbingan karir baik dipergunakan sebagai sarana informasi karir bagi siswa di SMA Negeri 1 Bulukumba.

4. Uji coba lapangan (field tryout).

Sampel dalam uji coba ini berjumlah 15 orang yang diketahui belum memiliki perencanaan karir yang baik.

Berdasarkan kelimabelas lembar evaluasi siswa yang telah diisi disimpulkan bahwa kegiatan ini menyenangkan buat mereka, serta memberikan pengetahuan selain mengenai perencanaan karir juga mengenai fungsi bimbingan konseling dan peran guru pembimbing yang sebenarnya, dimana yang mereka ketahui selama ini BK merupakan tempat pemberian hukuman bagi mereka yang memiliki kesalahan.

Untuk menguji keefektifan blog bimbingan karir peneliti menggunakan statistik non parametrik dengan metode wilcoxon melalui SPSS 20 dengan taraf kesalahan 5\%. Berdasarkan analisis tersebut diperoleh nilai Asympt Sig sebesar 0,001ini menandakan nilai Asympt Sig lebih kecil dari taraf kesalahan yang ditetapkan yaitu sebesar 0,05. Olehnya itu, disimpulkan bahwa blog Bimbingan Karir efektif digunakan sebagai sarana informasi dalam meningkatkan kemampuan perencanaan karir di SMA Negeri 1 Bulukumba.

Pembahasan dalam penelitian ini berawal dari adanya masalah yaitu tidak adanya jam khusus bagi guru pembimbing di SMA Negeri 1 Bulukumba yang mengakibatkan siswa di 
sekolah tersebut tidak memperoleh informasi karir sesuai dengan yang semestinya.

Terkait dengan perkembangan teknologi sekarang ini yang semakin canggih dan telah merambah segala aspek kehidupan manusia termasuk dalam proses pendidikan. Maka peneliti kemudian berinisiatif untuk mengembangkan media blog sebagai sarana informasi karir.

Blog yang dikembangkan diharapkan dapat menjadi media sekaligus model dalam pelaksanaan bimbingan karir yang kemudian menjadi pilihan bagi konselor selain melalui proses tatap muka. Ini dikarenakan blog ini berisi informasi mengenai cara merencanakan karir, informasi mengenai jenis-jenis studi lanjut, kode etik pelaksanaan BK di sekolah, penjelasan mengenai apa itu bimbingan karir serta pentingnya bagi siswa dan juga layanan tanya jawab yang memungkinkan siswa untuk memberikan pertanyaan seputar karir tanpa bertemu langsung dengan guru BK. Sebagaimana yang dikemukakan oleh Muttaqien (2011) mengenai kelebihan blog sebagai media dan sumber belajar alternatif berbasis yaitu dapat diakses oleh para siswa kapan saja dan dimana saja dan tidak harus melalui komputer, karena melalui handphone pun bisa.

\section{SIMPULAN DAN SARAN}

Berdasarkan penelitian yang dilakukan diperoleh kesimpulan sebagai berikut:

1. Berdasarkan analisis kebutuhan diketahui secara umum siswa di SMA Negeri 1 Bulukumba belum memiliki perencanaan karir yang baik. Namun disisi lain guru BK di sekolah tersebut tidak memiliki jam khusus sehingga pelaksanaan bimbingan karir tidak dapat dilaksanakan.

2. Hasil uji coba produk kepada beberapa ahli, yaitu ahli disimpulkan bahwa blog bimbingan karir baik dpergunakan sebagai sarana informasi karir bagi siswa di SMA Negeri 1 Bulukumba.

3. Berdasarkan hasil uji lapangan diperoleh kesimpulan bahwa blog Bimbingan karir efektif digunakan sebagai sarana informasi dalam meningkatkan kemampuan perencanaan karir di SMA Negeri 1 Bulukumba.

Saran bagi konselor Blog "Bimbingan Karir" dapat memudahkan kinerja konselor disekolah, terutama dari segi efisiensi waktu, olehnya itu konselor diharapkan menindaklanjuti pemberian informasi menggunakan media blog agar siswa dapat terbantu untuk merencanakan studi lanjut. bagi peneliti lain. Saran pengembangan secara umum untuk dapat mengembangkan materi layanan informasi studi lanjut menjadi lebih baik lagi, kemudian dari segi media, mungkin dapat mengembangkan layout-nya agar lebih menarik lagi untuk menarik minat siswa. Terakhir adalah agar peneliti selanjutnya yang berkeinginan untuk melakukan penelitian pengembangan agar dapat melaksanakan siklus pengembangan secara utuh. Bagi siswa Blog "Bimbingan Karir" ini adalah suatu media informasi yang berisikan informasi yang dibutuhkan oleh siswa mengenai karir. diantaranya informasi mengenai studi lanjut yang sekiranya penting bagi siswa yang ingin melanjutkan studi ke perguruan tinggi, olehnya itu siswa diharapkan untuk menindaklanjuti informasi yang ada dalam blog tersebut.

\section{DAFTAR RUJUKAN}

Efendi. 2013. Pengembangan Media Blog dalam Layanan Informasi Bimbingan dan Konseling. Jurnal BK UNESA (online), Vol. 1, No. 1, (http://ejournal.unesa.ac.id/index.php/jur nal-bk-unesa/article/view/1951/bacaartikel, Diakses 25 Februari 2014).

Falentini, F. 2013. Usaha Yang Dilakukan Siswa Dalam Menentukan Arah Pilihan Karir Dan Hambatan-Hambatan Yang Ditemui (Studi Deskriptif Terhadap Siswa SMAN 3 Payakumbuh). KONSELOR | Jurnal Ilmiah Konseling. Vol 2, No1. (http://ejournal.unp.ac.id/index.php/kons elor/article/view/1266, Diakses 13 Mei 2014).

Handono. 2013. Pengembangan Materi Layanan Informasi Studi Lanjut Melalui Media Blog di SMA Negeri 4 Bojonegoro. Jurnal BK UNESA, (online), Vol. 4 , No. 1 (http://ejournal.unesa.ac.id/inde x.php/jurnal bk unesa/article/view/6232/ baca-artikel, Diakses 25 Februari 2014).

Majid, Abdul. 2005. Perencanaan Pembelajaran (mengembangan kompetensi guru). Bandung: Rosdakarya.

Munir. 2008. Kurikulum Berbasis Teknologi Informasi dan Komunikasi (cetakan pertama). Bandung: Alfabeta. 
Nurjannah, S. 2013. Pengaruh Layanan Bimbingan Kelompok dengan teknik roleplaying terhadap perencanaan karir siswa kelas XI SMA Negeri 2 Pati Tahun pelajaran 2013/ 2014. Skripsi. Tidak Diterbitkan. Semarang: Program Studi Psikologi Pendidikan dan Bimbingan Fakultas Ilmu Pendidikan IKIP

PGRI Semarang. Tersedia: http://www.g oogle.com/url?sa=t\&rct=j\&q=\&esrc=s\& source $=$ web $\&$ cd $=4 \& v e d=0 \mathrm{CDoQFj} A D$ \&url=http $\% 3 \mathrm{~A} \% 2 \mathrm{~F} \% 2 \mathrm{Flibrary}$. ikippgris mg.ac.id $\% 2$ Fdocfiles $\% 2$ Ffulltext $\% 2$ F02 c6c7eb09a91a5e.pdf\&ei=fhl2U4n1K8fsr Afn-

YCYBw\&usg=AFQjCNGrAgtFVpFoqK asYg_oXy-

Xxmfusg\&bvm=bv.66699033,d.bmk.

Purnamasari, A. 2006. Efektivitas Pelatihan Perencanaan Karir Untuk Meningkatkan Kejelasan Arah Pilihan Bidang Minat Karir Pada Mahasiswa Semester III Fakutas Psikologi. Humanitas: Indonesian Psychological Journal. Vol. 3 , No. (journal.uad.ac.id/index.php/HUMANIT AS/article/view/730/395, Diakses 13 Mei 2014).

Sanjaya, Wina. 2008. Perencanaan dan Desain Sistem Pembelajaran (cetakan pertama). Jakarta: Kencana Prenada Media Group.

Santosa. 2007. Pemanfaatan Blog (Jurnal Online) dalam Pembelajaran Menulis (online), (http://blog.umy.ac.id/topik/files/2012/0 1/contoh-jurnal-pendidikanpemanfaatan-blog.pdf, Diakses 26 Februari 2014).

Setyani. 2013. Penggunaan Media Sosial Sebagai Sarana Komunikasi Bagi Komunitas (online), (http://jurnal-komm as.com/docs/JURNAL\%20Novia\%20Ika .pdf, Diakses 24 Februari 2014). 